\title{
Estimation of the accuracy of joint mobility assessment in a group of health professionals
}

\author{
B. Banskota $\cdot$ J. Lewis $\cdot$ M. Hossain $\cdot$ A. Irving $\cdot$ \\ M. W. Jones
}

Published online: 9 April 2008

(C) Springer-Verlag 2008

Erratum to: Eur J Orthop Surg Traumatol

DOI 10.1007/s00590-008-0301-1

Unfortunately, one of the authors' name was spelled incorrectly. Please note that A. Irvine should read as A. Irving.

The online version of the original article can be found under doi:10.1007/s00590-008-0301-1.

B. Banskota · J. Lewis · M. Hossain · A. Irving · M. W. Jones Department of Trauma and Orthopaedic Surgery,

Ysbyty Gwynedd Hospital, Penrhosgarnedd Road,

Bangor LL57 2PW, UK

M. Hossain ( $\square)$

101, Taliesin Court, Cardiff CF10 5NJ, UK

e-mail: munierh@doctors.org.uk 